\title{
Avulsion fracture of the proximal fibula (arcuate sign) in a young woman
}

\author{
Stephen Spadafore, ${ }^{1}$ Morteza Khodaee (1) ${ }^{2}$
}

${ }^{1}$ Family Medicine, University of Colorado Denver School of Medicine, Denver, Colorado, USA

${ }^{2}$ Family Medicine and Orthopedics, University of Colorado Denver School of Medicine, Denver, Colorado, USA

\section{Correspondence to} Professor Morteza Khodaee; morteza.khodaee@cuanschutz. edu

Accepted 14 July 2020

\section{DESCRIPTION}

A 20-year-old woman presented to our primary care clinic for right knee pain 2 weeks after she was struck on her right side by a car travelling $10 \mathrm{mph}$ (16 kph). She was seen in an emergency department after the accident and diagnosed with right superior and inferior pubic rami fractures but did not have any imaging of her right knee. The pain is constant, worsens with weight bearing, and has not been relieved by non-steroidal antiinflammatory drugs (NSAIDs) or ice. It is aching in quality and worst on the lateral aspect. Her knee has also become gradually more swollen since the accident and feels unstable with weight bearing. She denies locking and clicking of the knee. She denies weakness, numbness and tingling of her leg. On physical examination, her gait is antalgic with mild right knee effusion. Range of motion is from $0^{\circ}$ to $120^{\circ}$ with pain at end range of motion. There is tenderness to palpation of the fibular head, but no tenderness of the medial or lateral joint lines, patella, patellar tendon, lateral collateral ligament (LCL) or medial collateral ligament (MCL). There is $1+$ glide with Lachman, but negative anterior and posterior drawer tests. There is no laxity with varus and valgus stress and the leg is neurovascularly intact. Plain radiography revealed an avulsion fracture of the proximal fibula (figure 1).

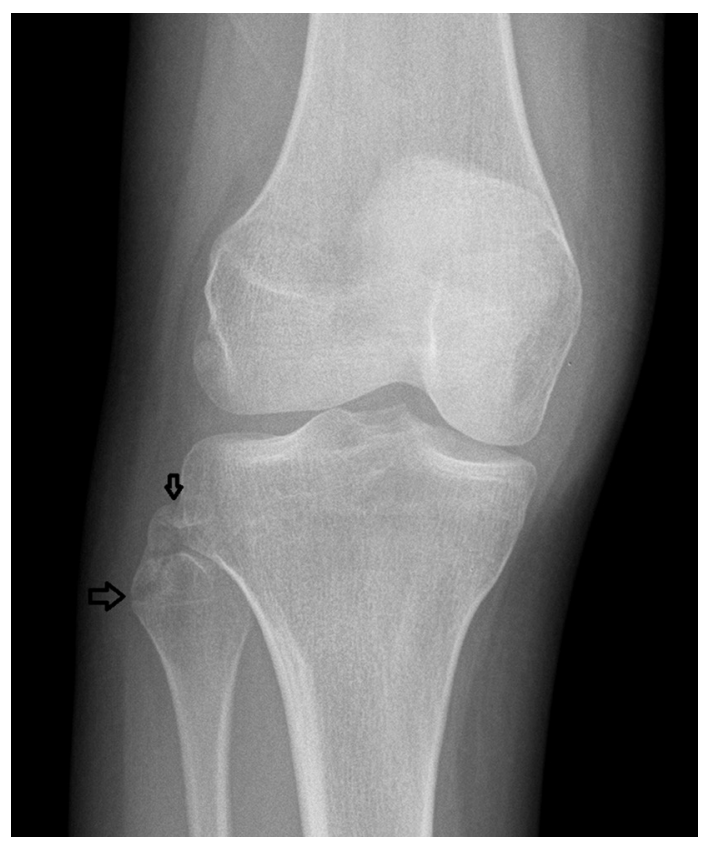

Figure 1 Anteroposterior plain radiography 2 weeks after injury reveals an avulsion fracture of the proximal fibula (arrows) at the attachment of the arcuate ligament.

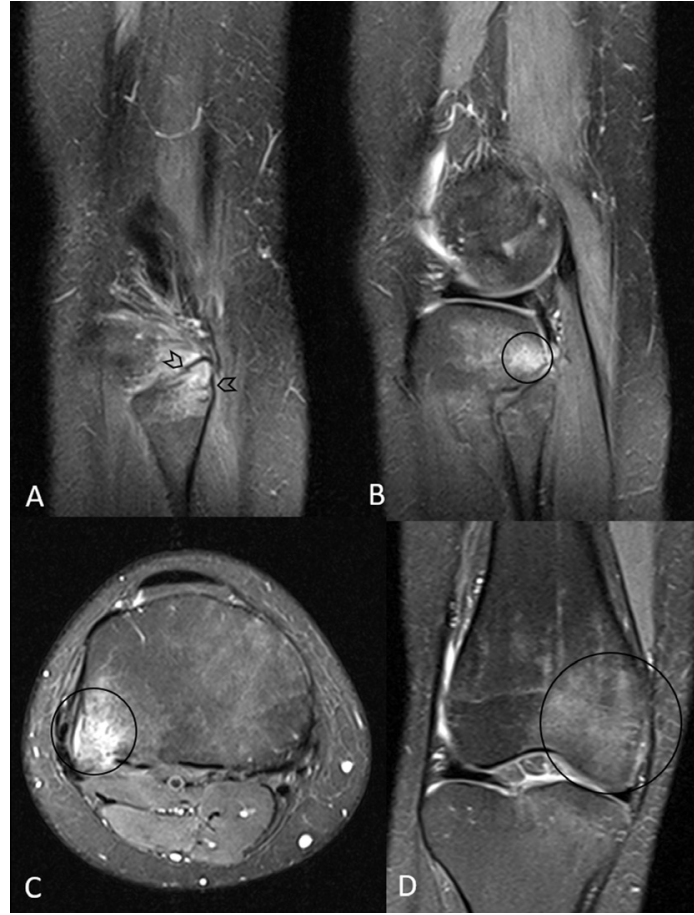

Figure 2 T2 weighted MRI images 4 weeks after the injury (A-D). Sagital view (A) confirms the avulsion fracture of the proximal fibula (arrowheads). Sagital (B) and transverse $(C)$ views also show impaction oedema at the adjacent posterior lateral tibial plateau (circles). Coronal view (D) revealed severe bone marrow contusion of the medial femoral condyle (circle). Anterior cruciate ligament, posterior cruciate ligament, medial collateral ligament and lateral collateral ligament complex including the popliteus tendon were normal.

MRI (figure 2) showed impaction oedema and bone marrow contusion at the posteriolateral tibial plateau and medial femoral condyle with intact anterior cruciate ligament (ACL), posterior cruciate ligament (PCL), MCL and LCL. She was treated conservatively with relative rest, ice and NSAIDs as needed. At 4-week follow-up, her pain and swelling had decreased significantly, and her feeling of instability resolved. She started formal physical therapy, including a home exercise programme for muscle strengthening. At 10-week follow-up, her pain and function had returned to her pre-injury baseline.

A fibular head avulsion fracture occurs at the insertion of the posterolateral ligamentous complex and is called the 'arcuate' sign when identified on plain radiograph. ${ }^{1-5}$ It is an important finding that frequently indicates other underlying structural injury to the knee. ${ }^{1-5}$ This fracture is highly 


\section{Learning points}

- Avulsion fracture of the proximal fibula, 'arcuate sign', is a rare finding on plain radiography.

- Due to high association of arcuate sign and internal derangement of the knee (eg, anterior cruciate ligament, posterior cruciate ligament and posterolateral corner injuries), an MRI should be obtained.

- Patients with arcuate sign and no major ligaments or soft tissue injuries can be treated non-operatively.

associated with a rupture of either the ACL or PCL, or an injury to the posterolateral corner of the knee. ${ }^{1-5}$ If left untreated, these injuries can lead to posterolateral instability of the knee. ${ }^{3}$ The most common mechanism of injury is direct force to the anteromedial knee with tibia externally rotated or hyperextension force with tibia internally rotated. ${ }^{34}$ Anteroposterior is the best view to visualise the arcuate sign in plain radiography. ${ }^{3-5}$ MRI should be obtained to evaluate ACL, PCL and posterolateral corner injuries. ${ }^{35}$ In patients without any major ligamentous injuries, a nonoperative management is the treatment of choice which includes weight bearing as tolerated and rehabilitation.
Contributors SS and MK participated in patient's care, literature review, manuscript preparation and approval.

Funding The authors have not declared a specific grant for this research from any funding agency in the public, commercial or not-for-profit sectors.

Competing interests None declared.

Patient consent for publication Obtained.

Provenance and peer review Not commissioned; externally peer reviewed.

\section{ORCID iD}

Morteza Khodaee http://orcid.org/0000-0003-3549-5333

\section{REFERENCES}

1 Lee $\mathrm{CH}$, Tan CF, Kim O, et al. Osseous injury associated with ligamentous tear of the knee. Can Assoc Radiol J 2016;67:379-86.

2 Lee J, Papakonstantinou O, Brookenthal KR, et al. Arcuate sign of posterolateral knee injuries: anatomic, radiographic, and MR imaging data related to patterns of injury. Skeletal Radiol 2003:32:619-27.

3 Huang G-S, Yu JS, Munshi M, et al. Avulsion fracture of the head of the fibula (the "arcuate" sign): MR imaging findings predictive of injuries to the posterolateral ligaments and posterior cruciate ligament. AJR Am J Roentgenol 2003;180:381-7.

4 Strub WM. The arcuate sign. Radiology 2007;244:620-1.

5 Juhng S-K, Lee JK, Choi S-S, et al. MR evaluation of the "arcuate" sign of posterolateral knee instability. AJR Am J Roentgenol 2002;178:583-8.

Copyright 2020 BMJ Publishing Group. All rights reserved. For permission to reuse any of this content visit https://www.bmj.com/company/products-services/rights-and-licensing/permissions/

BMJ Case Report Fellows may re-use this article for personal use and teaching without any further permission.

Become a Fellow of BMJ Case Reports today and you can:

- Submit as many cases as you like

- Enjoy fast sympathetic peer review and rapid publication of accepted articles

- Access all the published articles

- Re-use any of the published material for personal use and teaching without further permission

Customer Service

If you have any further queries about your subscription, please contact our customer services team on +44 (0) 2071111105 or via email at support@bmj.com.

Visit casereports.bmj.com for more articles like this and to become a Fellow 